\title{
GENETIC RELATIONSHIPS AMONG FOUR MUTELID SPECIES (BIVALVIA: UNIONIDA) IN EGYPT REVEALED BY RAPD-PCR TECHNIQUE
}

\author{
Mona F. Fol ${ }^{1}$; Mostafa Y. Morad ${ }^{2}$; Irene S. Gamil' ${ }^{2}$, Salwa F. Sabet ${ }^{1}$; \\ Reda M. Mansour ${ }^{2 *}$ \\ ${ }^{\mathbf{1}}$ Zoology Department, Faculty of Sciences, Cairo University, Giza, Egypt \\ ${ }^{2}$ Zoology and Entomology Department, Faculty of Science, Helwan University, Cairo, Egypt
}

\author{
Article History: \\ Received: 28 September 2020 \\ Revised: 27 November 2020 \\ Accepted: 30 November 2020 \\ Published Online: \\ 1 December 2020 \\ Keywords: \\ Chambardia letourneuxi \\ Chambardia rubens \\ Mutela dubia \\ Mutela rostrata \\ RAPD-PCR

*Correspondence:
Reda Mansour
Zoology and Entomology
Department, Faculty of Science
Helwan University
Cairo, Egypt
E-mail:
reda_mansour@science.helwan.
edu.eg \\ *Correspondence: \\ a Mansou \\ Zoology and Entomology \\ Helwan University \\ Cairo, Egypt \\ reda_mansour@science.helwan. \\ edu.eg
}

\begin{abstract}
Random amplified polymorphic deoxyribonucleic acidpolymerase chain reaction (RAPD-PCR) is considered as one of the simple and quick methods that are used to resolve the genetic relationship among species of taxa that are difficult to identify on the basis of morphological characters. Bivalves show great morphological variations that couple with relatively few constant characters rendering them a systematically difficult group, and many of them have numerous subspecies and several synonyms. Due to the high degree of morphological variability within Order Unionoida, four species: Mutela dubia, $M$. rostrata, Chambardia rubens, and C. letourneuxi were collected from Benha region (Qaluobiya Governorate, Egypt) to resolve their degree of genetic similarity depending on RAPD-PCR technique. Out of six primers used, only five primers "UBC476, UBC477, UBC478, UBC483, and UBC486" worked successfully. The study revealed that $C$. rubens and C. letourneuxi are very closely related species, as they showed closely similar bands on using the primers UBC477, UBC483, and UBC486.
\end{abstract}

\section{INTRODUCTION}

Recent molecular approaches in taxonomy have led to a steady increase in the identification of cryptic species. Prior to molecular techniques, evolutionary relationships among bivalves were determined using morphological species concepts ${ }^{[1]}$. The advent of molecular techniques has revealed that some morphological characters, such as shell structures in bivalves, are highly polymorphic and any change due to environmental and population density can affect these characters ${ }^{[2]}$. In Egypt, the species of family Mutelidae have showed so variable shell morphology due to environmental changes and geographical distribution leading to confusion in their nomenclature and classification ${ }^{[3-5]}$. Ibrahim et $a l .{ }^{[3]}$ reported that within Mutelidae there are only two genera found in Egypt namely, Mutela and Chambardia. Mutela was reported to have three species; Mutela dubia, $M$. rostrata, and $M$. singularis; while genus Chambardia has two species, 
Chambardia rubens and C. letourneuxi. On the other hand, Harper et al. ${ }^{[4]}$ and El-Assal et $a l .{ }^{[5]}$ have separated each of Mutela and Chambardia into only two species. Based on the morphological characters, shells of Mutela spp. devoid the umbonal sculpture, while Chambardia spp. have shells with umbonal sculpture. Shells of $M$. dubia and $C$. rubens are ovateelongate, while those of $M$. rostrata and C. letourneuxi are elongate. In addition, shell of $M$. dubia has posterior dorsal margin showing the largest height, while $M$. rostrata has dorsal and ventral margins that are almost parallel. On the other hand, $C$. rubens has shell length/height $(\mathrm{L} / \mathrm{H})$ ratio equals to 1.6 , while that of $C$. letourneuxi has $\mathrm{L} / \mathrm{H}$ ratio measuring $1.8-2.0^{[3]}$.

One of the DNA features that were used to analyse the population genetic diversity is random amplified polymorphic DNApolymerase chain reaction (RAPD-PCR) technique. RAPD-PCR standard method uses short-single oligonucleotide (10-12 bases) with the random order as a primer to amplify DNA genes in nanograms in low annealing temperature ${ }^{[6]}$. Therefore, the present study aimed to use RAPD-PCR method to determine the degree of genetic similarity and evaluate the genetic relationship among the four mutelid species, M. dubia, M. rostrata, C. rubens, and C. letourneuxi from the River Nile in Egypt.

\section{MATERIAL AND METHODS Collection of samples}

Samples of the four mutelid species, M. dubia, M. rostrata, C. rubens, and C. letourneuxi ( $\mathrm{n}=5$, for each species) were collected from Benha (Qaluobiya Governorate) along River Nile in Egypt (Figure 1) using a special net made of hard metallic frame. Mussels were collected during spring 2017 and transferred to the laboratory of Invertebrates. Sorting and maintenance of samples were done under the standard conditions of food and temperature. Identification of mussels followed the keys of Ibrahim et al. ${ }^{[3]}$ and Graf and Cummings ${ }^{[7]}$.

\section{Extraction of DNA and RAPD-PCR technique}

The four samples under investigation were dissected and preservation of their soft parts was carried out in absolute ethanol at $-20^{\circ} \mathrm{C}$ until utilization. The extraction of total genomic DNA from frozen alcoholpreserved foot was achieved using Qiagen DNeasy tissue kit (Valencia, Santa Clarita, CA, USA) following the manufacturer's instruction. Six primers were used in the present investigation in RAPD-PCR ${ }^{[8-11]}$ : 476: 5 -TTGAGGCCCT-3', 477: 5'-TGTT GTGCCC-3`, 478: 5`-CGAGCTGGTC-3`, 479: 5'CTCATACGCG-3`，483：5`-GCA CTAAGAC-3`, 486: 5'-CCAGCATCAG-3` (Midland Certified Reagent Company, Midland, TX, USA).

In the preliminary experiments, only five primers worked successfully "UBC476, UBC477, UBC478, UBC483, and UBC486". Amplifications were practiced following Williams et al. ${ }^{[12]}$ with some modifications. PCR mixture $(50 \mu \mathrm{L})$ contained $2.0 \mu \mathrm{L}$ sample DNA, $1.0 \mu \mathrm{L}$ primer, $25 \mu \mathrm{L}$ master mix and $22 \mu \mathrm{L}$ distilled water (PCR MyTaq $^{\text {TM }}$ HS Red Mix, Bioline, Memphis, TN, USA). By utilization of each primer, each amplification reaction was repeated three times to verify band autosimilarity ${ }^{[13]}$. Amplifications were produced in T-personal thermal cycler (TC-3000G, Techne Inc., Burlington, NJ, USA), programmed for 45 cycles of $94^{\circ} \mathrm{C}$ for 1.0 minute, $35^{\circ} \mathrm{C}$ for 1.0 minute, and $72^{\circ} \mathrm{C}$ for 1.0 minute. An initial denaturation step for 3.0 minutes at $94^{\circ} \mathrm{C}$ and a final extension holding for 10 minutes at $72^{\circ} \mathrm{C}$ were included in the first and last cycles, respectively. The reaction products $(10 \mu \mathrm{L})$ were resolved by $2.0 \%$ agarose gel electrophoresis at $85 \mathrm{~V}$ in $1.0 \times$ Tris-acetate-EDTA (TAE) buffer. The gel was visualized using ethidium bromide stain and then photographed with gel documentation system (SynGene, GeneTools - File version: 4.02.03, France). Species-specific fragments were revealed using GeneRuler $1.0 \mathrm{~kb}$ Plus DNA Ladder (Fisher Scientific, Toronto, Canada) to compare the amplified products. 

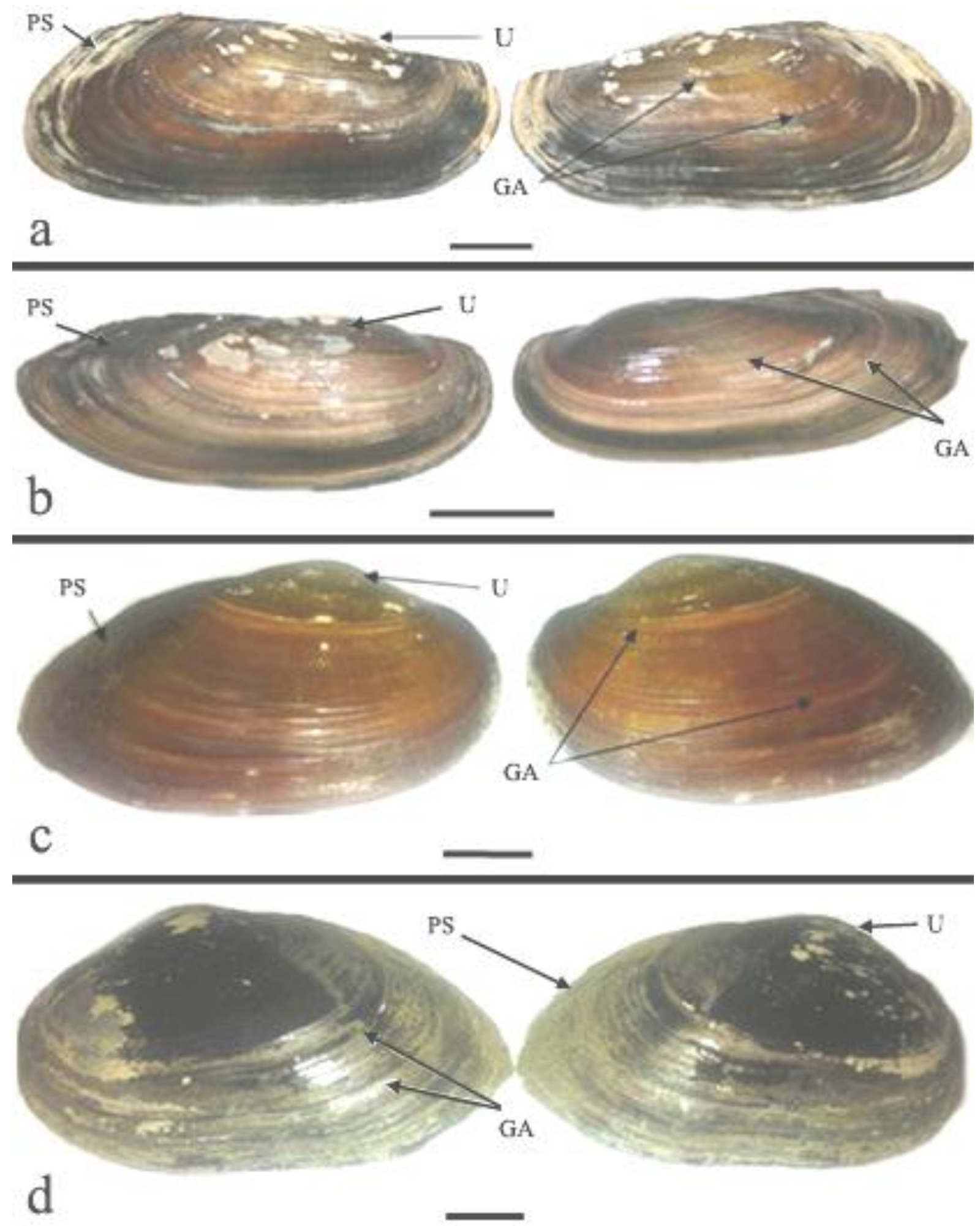

Figure 1: Photographs showing the morphology of external shell surface of the four mutelid species: (a) Mutela dubia shell; (b) M. rostrata shell; (c) Chambardia rubens shell; (d) C. letourneuxi shell. GA: growth annuli, PS: posterior slope, U: umbo. Scale bar $=2 \mathrm{~cm}$.

\section{Molecular data analysis}

Molecular analysis was executed using gel documentation system for the dendogram and estimation of similarity index (D-value) of each primer among the studied mutelid species. RAPD-PCR amplification products 
took the score $1 / 0$ for presence/absence of homologous bands ${ }^{[14]}$ and analyses were accomplished using the NTSYSpc 2.2 software $^{[15]}$. For RAPD markers, similarity coefficient matrix was calculated using Jaccard similarity algorithm ${ }^{[16]}$. Construction of dendograms was done using the unweighed pair-group method with arithmetical algorithms averages (UPGMA $)^{[17]}$. Genetic diversity was also revealed as the percentage of polymorphic bands. The percentage of polymorphism was calculated for each species, as well as the mean and overall value for all species and each primer.

\section{RESULTS}

DNA was successfully extracted from the foot of the four studied species; Mutela dubia, M. rostrata, Chambardia rubens, and C. letourneuxi. RAPD-PCR was carried out using six primers of which, primer (UBC 479) gave no reproducibility for all studied species, while the other five primers provided strongly amplified fragments (Figures 2-6).

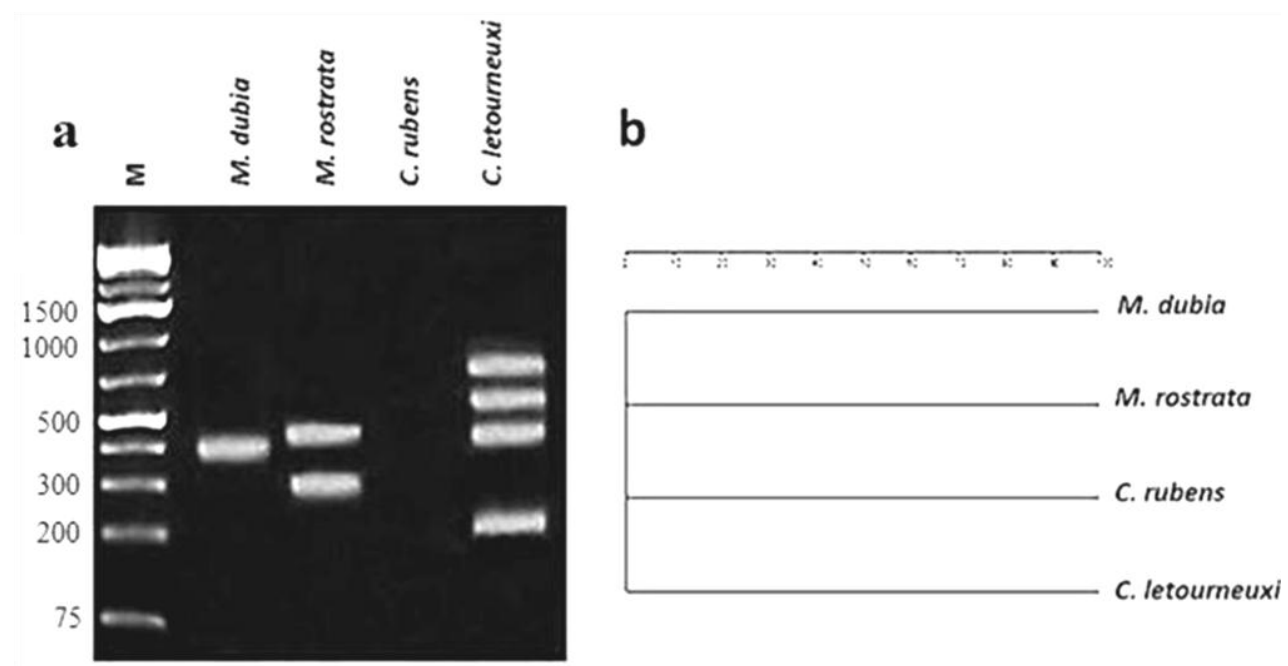

Figure 2: RAPD-PCR profile of the mutelid species using UBC476 primer. (a) Gel electrophoresis showing amplification profile of samples, $\mathrm{M}: 1.0 \mathrm{~kb}$ DNA marker, (b) dendrogram of UBC476 primer demonstrating the relationships of the species under study.

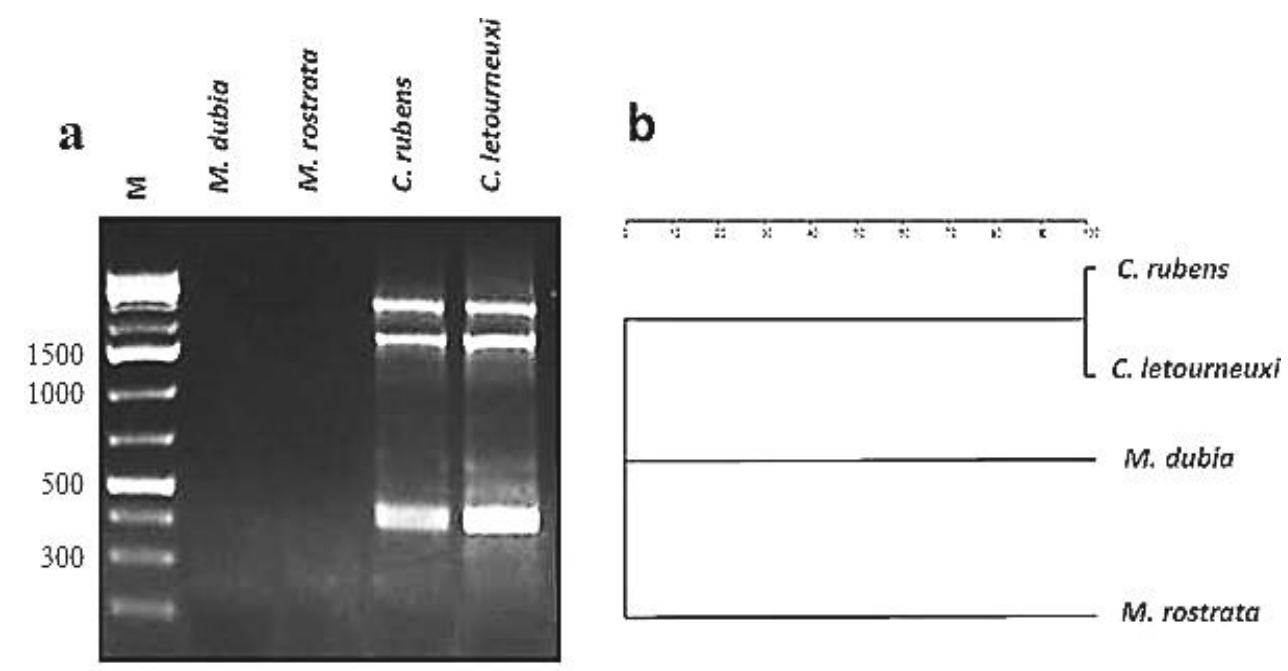

Figure 3: RAPD-PCR profile of the mutelid species using UBC477 primer. (a) Gel electrophoresis showing amplification profile of samples, $\mathrm{M}: 1.0 \mathrm{~kb}$ DNA marker, (b) dendrogram of UBC477 primer demonstrating the relationships of the species under study. 


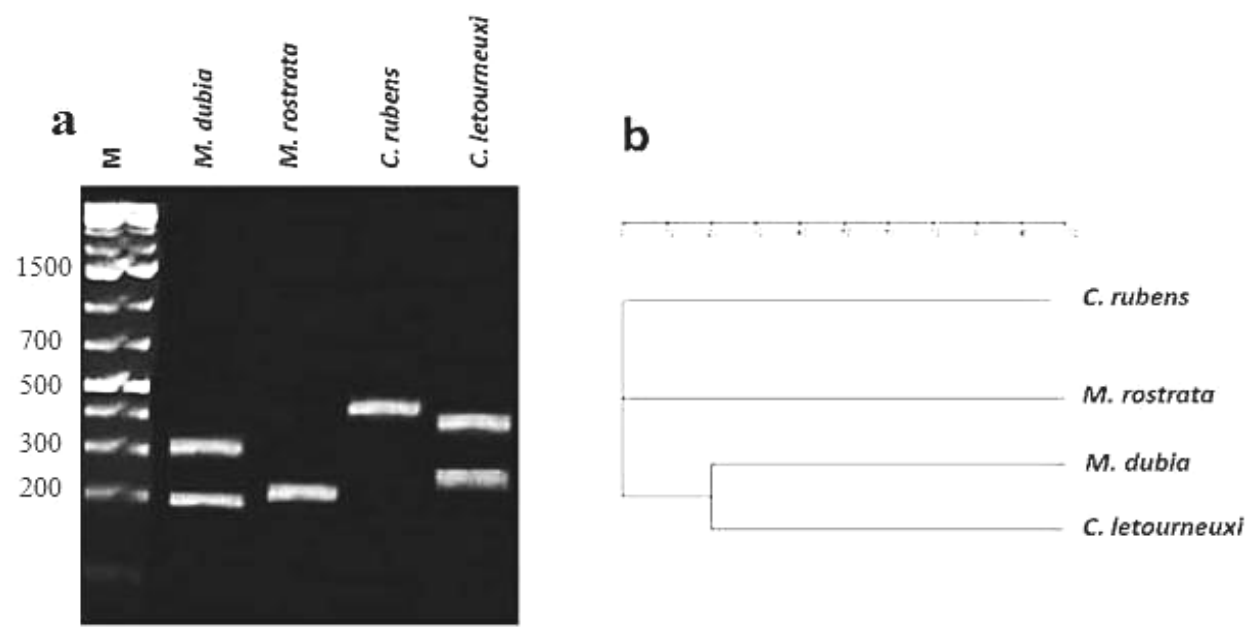

Figure 4: RAPD-PCR profile of the mutelid species using UBC478 primer. (a) Gel electrophoresis showing amplification profile of samples, $\mathrm{M}: 1.0 \mathrm{~kb}$ DNA marker, (b) dendrogram of UBC478 primer demonstrating the relationships of the species under study.

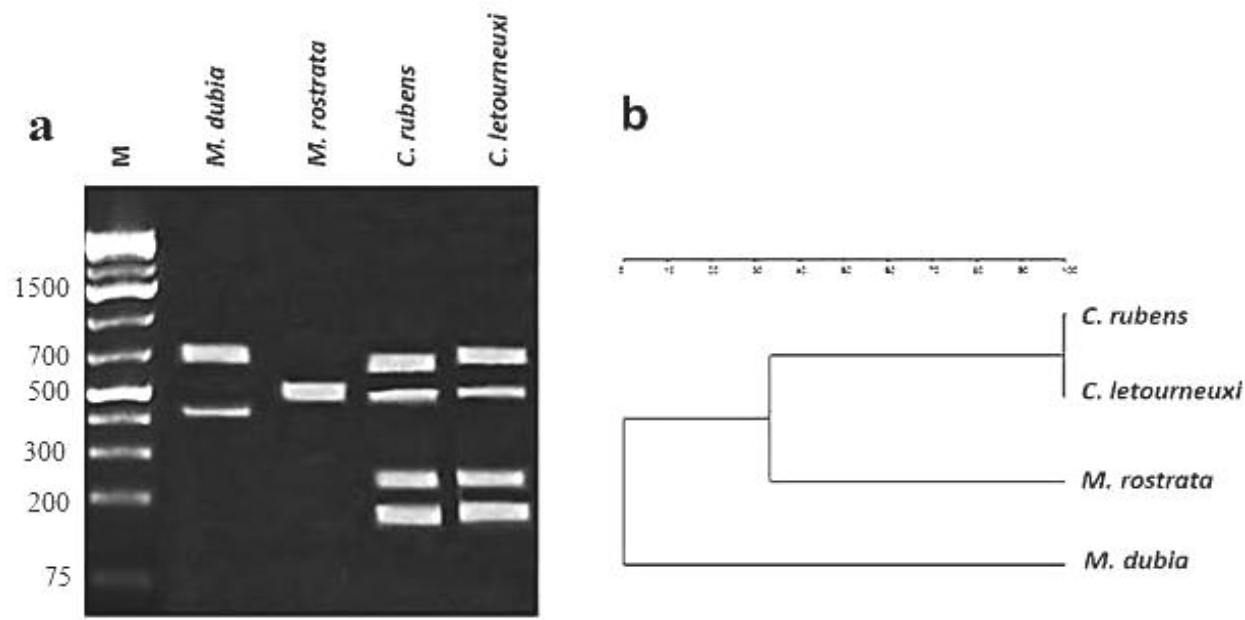

Figure 5: RAPD-PCR profile of the mutelid species using UBC483 primer. (a) Gel electrophoresis showing amplification profile of samples, $\mathrm{M}: 1.0 \mathrm{~kb}$ DNA marker, (b) dendrogram of UBC483 primer demonstrating the relationships of the species under study.

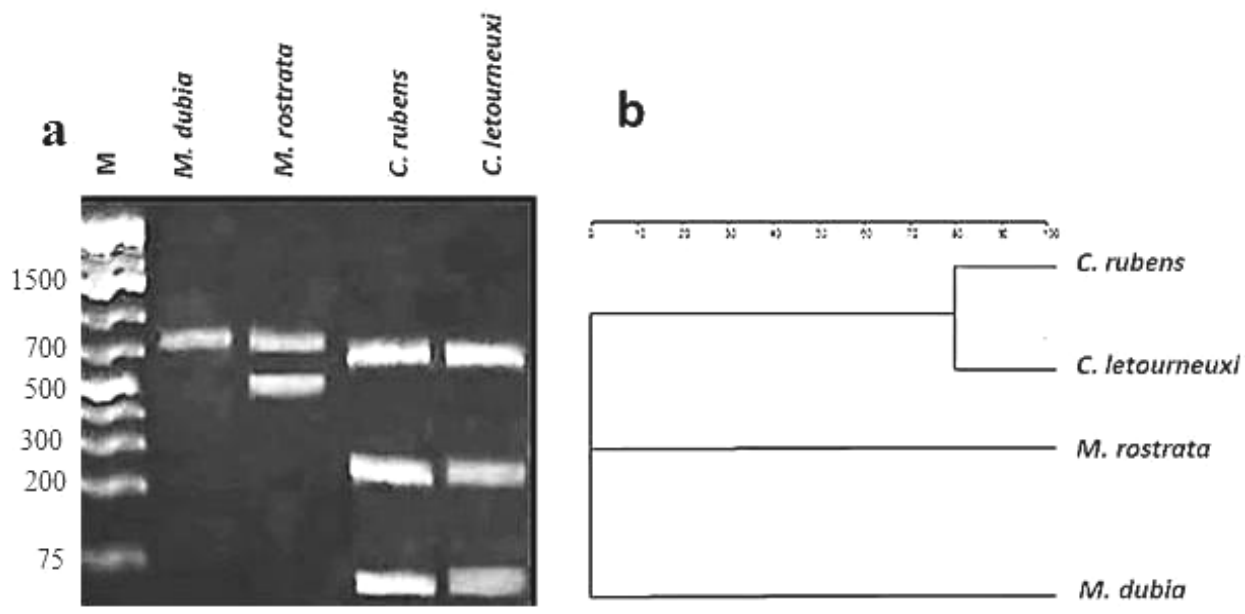

Figure 6: RAPD-PCR profile of the mutelid species using UBC486 primer. (a) Gel electrophoresis showing amplification profile of samples, $\mathrm{M}: 1.0 \mathrm{~kb}$ DNA marker, (b) dendrogram of UBC486 primer demonstrating the relationships of the species under study. 
Each primer produced 3-6 polymorphic bands (Table 1). The number of amplified bands (monomorphic, polymorphic, and unique) of the DNA of each species with different primers is given, and the genetic diversity is also given as the percentage of the polymorphic bands for each primer
(Table 1). Some RAPD-PCR fragments were found to be unique; four unique bands in $M$. dubia, one unique band in $M$. rostrata, one unique band in $C$. rubens, and six unique bands in $C$. letourneuxi, while the total polymorphic bands were found to be $90 \%$ among the four studied species (Table 2).

Table 1: Total number of bands (monomorphic and polymorphic) and the percentage of polymorphism of each primer in samples under investigation.

\begin{tabular}{ccccc}
\hline Primers & Total bands number & Monomorphic & Polymorphic & Polymorphism (\%) \\
\hline UBC476 & 6 & 0 & 6 & $100 \%$ \\
UBC477 & 3 & 0 & 3 & $100 \%$ \\
UBC478 & 5 & 0 & 5 & $100 \%$ \\
UBC483 & 5 & 0 & 5 & $100 \%$ \\
UBC486 & 4 & 0 & 4 & $100 \%$ \\
\hline
\end{tabular}

Table 2: Total number of bands for all studied primers (monomorphic, polymorphic, and unique) and the percentage of polymorphism revealed by RAPD markers among the four mutelid species.

\begin{tabular}{lccccc}
\hline Bands & M. dubia & M. rostrata & C. rubens & C. letourneuxi & Total \\
\hline Amplified & 6 & 6 & 11 & 16 & 39 \\
Monomorphic & 1 & 1 & 1 & 1 & 4 \\
Polymorphic & 5 & 5 & 10 & 15 & 35 \\
Unique & 4 & 1 & 1 & 6 & 12 \\
Polymorphism (\%) & $83 \%$ & $83 \%$ & $90 \%$ & $94 \%$ & $90 \%$ \\
\hline
\end{tabular}

By running PCR products of the studied samples on agarose gel, the genetic variability was observed among the studied Mutela and Chambardia species. The RAPD-PCR analysis was based on the number of bands that were different between any given pair of species (Figures 2-6). Analysis showed natural differences or polymorphism among the studied Mutela and Chambardia species under investigation. Results of RAPD-PCR using UBC477, UBC483, and UBC486 primers indicated that $C$. rubens and $C$. letourneuxi showed bands at about the similar base pairs on using the same primers (Figures 3a, 5a, and 6a). No differences between the four studied species were shown using the primers UBC476 and UBC478 (Figures 2a and 4a). In addition, the dendrogram analysis using the primers UBC477, UBC483, and UBC486 (Figures 3b, 5b, and 6b) confirmed the results obtained with the RAPD-PCR profile and those of the D-values, where $C$. rubens and $C$. letourneuxi are the closest species, while $M$. dubia and $M$. rostrata are distinct ones.

D-values of the studied species is presented in Table " 3 ". Species are considered similar when the D-value between two species is equal or close to 1.0. 
Table 3: Similarity indices (D-values) of the studied species using the current five primers.

\begin{tabular}{lcccc}
\hline \multicolumn{1}{r}{ Species } & M. dubia & M. rostrata & C. rubens & C. letourneuxi \\
\hline M. dubia & 1 & UBC476 & & \\
M. rostrata & 0 & 1 & & \\
C. rubens & 0 & 0 & 1 & \\
C. letourneuxi & 0 & 0 & 0 & 1 \\
\hline
\end{tabular}

UBC477

\begin{tabular}{|c|c|c|c|c|}
\hline M. dubia & 1 & & & \\
\hline M. rostrata & 0 & 1 & & \\
\hline C. rubens & 0 & 0 & 1 & \\
\hline C. letourneuxi & 0 & 0 & 1 & 1 \\
\hline
\end{tabular}

\section{$\mathrm{UBC} 478$}

\begin{tabular}{lcccc} 
M. dubia & 1 & & & \\
M. rostrata & 0 & 1 & & \\
C. rubens & 0 & 0 & 1 & 1 \\
C. letourneuxi & 0.2 & 0 & 0 & \\
\hline
\end{tabular}

UBC483

\begin{tabular}{lcccc}
$M$. dubia & 1 & & & \\
M. rostrata & 0 & 1 & & \\
C. rubens & 0 & 0.33 & 1 & 1 \\
C. letourneuxi & 0 & 0.33 & 1 & \\
\hline
\end{tabular}

UBC486

\begin{tabular}{|c|c|c|c|c|}
\hline M. dubia & 1 & & & \\
\hline M. rostrata & 0 & 1 & & \\
\hline C. rubens & 0 & 0 & 1 & \\
\hline C. letourneuxi & 0 & 0 & 0.8 & 1 \\
\hline
\end{tabular}

On the other hand, when D-value is distant from 1.0, the two species are considered as separate species. D-values between $C$. rubens and $C$. letourneuxi using the primers UBC477, UBC483, and UBC486 was found to be close to 1.0 , while it was distant from 1.0 for these two species and the other studied species using the primers UBC476 and UBC478 indicating no close relationship (Table 3). As a result, $C$. rubens and $C$. letourneuxi were found to be the closest species. The similarity coefficient matrix of all primers showed that the highest D-value (0.75) was found between $C$. rubens and $C$. letourneuxi, while the lowest D-value (0.12) was obtained between $M$. dubia and C. letourneuxi (Table 4). Moreover, the UPGMA dendrogram of all primers (Figure 7) revealed that $C$. rubens and $C$. letourneuxi are the most closely associated species, while M. dubia and $M$. rostrata are distinct ones. 
Table 4: Similarity coefficient matrix of all primers calculated by NTSys of the studied mutelid species.

\begin{tabular}{lcccc}
\hline \multicolumn{1}{c}{ Species } & M. dubia & M. rostrata & C. rubens & C. letourneuxi \\
\hline M. dubia & 1 & & & \\
M. rostrata & 0.56 & 1 & & \\
C. rubens & 0.37 & 0.43 & 1 & \\
C. letourneuxi & 0.12 & 0.31 & 0.75 & 1 \\
\hline
\end{tabular}
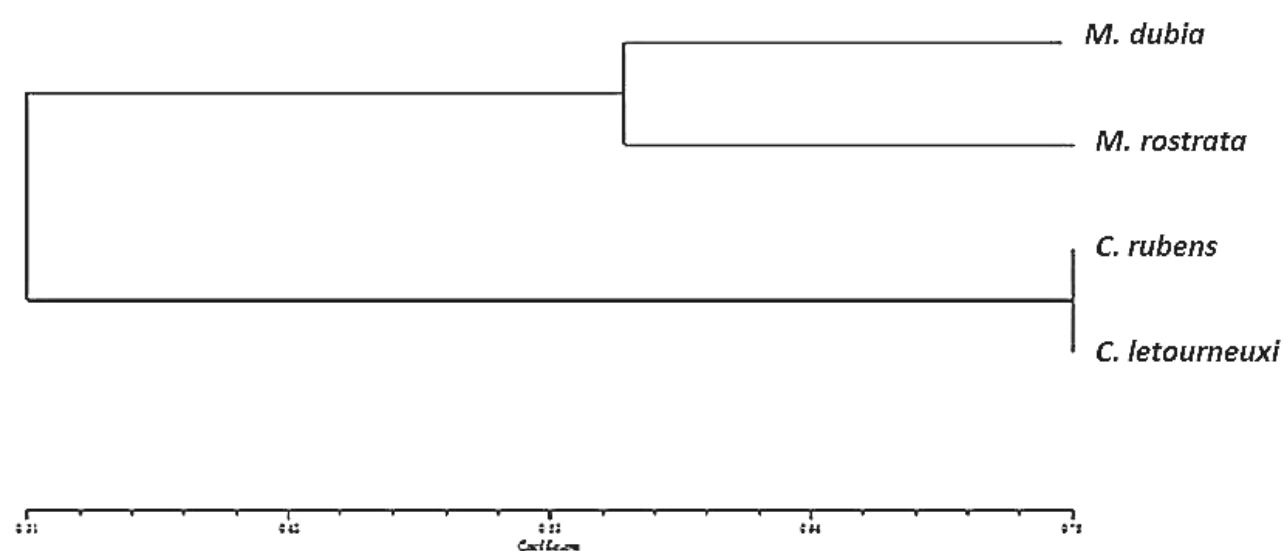

Figure 7: Dendrogram of cluster analysis for the four studied species according to RAPDPCR data obtained using Jaccard coefficient and unweighed pair-group method with arithmetical algorithms averages (UPGMA).

\section{DISCUSSION}

The importance of taxonomy by using DNA analyses contrasts with morphological studies in biodiversity research ${ }^{[18]}$. The exclusive reliance on one or other method may fail to detect variations. Comprehensive studies including morphometrics and molecular analyses may provide a more accurate approach to species discrimination. The genetic analyses of bivalve species identifications have been used to correct mislabelling ${ }^{[19,20]}$. Species determination by means of molecular techniques could bypass the problems of interspecific convergence and intraspecific variability, often impeding accurate morphological identification of freshwater mussels ${ }^{[21-23]}$. RAPD-PCRs are commonly used as markers to discriminate between particular taxa by the presence or absence of certain diagnostic RAPD-PCR bands ${ }^{[11]}$. In addition, the molecular data have been confirmed as an effective tool for studying species with variable phenotypic plasticity $^{[24,25]}$.

In molluscs, many previous results were obtained by different research groups ${ }^{\text {[26-29] }}$ indicated that RAPD-PCR was an adequate technique and a good initial approach for distinguishing between morphologically close species and even among the different populations within the same species. In addition, Bin Dajem et al. ${ }^{[30]}$ and Oliveira et al. ${ }^{[31]}$ amplified the genomic DNA and the extracted PCR products from Biomphalaria spp. and reported a fingerprint pattern unique to these snails. They analysed RAPD-PCR products using agarose gel as good, easy, rapid, and cheap method, while other groups of researchers used the alternative polyacrylamide gel electrophoresis method ${ }^{[25,32-34]}$.

RAPD-PCR method was successfully used to determine genetic relationships among molluscs. Adult specimens of the 
two common freshwater bivalves, Caelatura companyoi and Caelatura prasidens belonging to family Unionidae were described by some authors as one species ${ }^{[35]}$, while Ibrahim et al. ${ }^{[3]}$ separated them as two different species. RAPD-PCR markers were used and confirmed that the two specimens should be actually separated as two different species ${ }^{[9]}$. RAPD-PCR carried out to solve the problem of confusion between Coelatura species and showed that the five distinct morphologically species of Coelatura, may be only three different species namely Coelatura aegyptiaca, C. canopicus, C. parreyssi ${ }^{[11]}$. Therefore, the determination of genetic similarity degree for some of the species is necessary, using technique like RAPD-PCR.

As far as is known, no previous RAPDPCR analysis has been so far carried out on the freshwater bivalves family Iridinidae species found in Egypt. The current study presents a degree of genetic convergence for the mutelid species inhabiting the River Nile in Egypt, facilitating quick, low-cost, accurate, and reliable determination of adult specimens. RAPD-PCR analysis showed natural differences or polymorphism among mutelid species under investigation. In addition, dendrograms and D-values showed that there are differences among the four studied species, using the five primers: UBC476, UBC477, UBC478, UBC483, and UBC486. Genetic diversity was measured as the percentage of polymorphic bands, $90 \%$ of the bands were polymorphic among the four studied species. Some RAPD-PCR fragments were found to be unique to a particular species; four unique bands were found in $M$. dubia, one unique band was found in $M$. rostrata and $C$. rubens, and six unique bands were found in C. letourneuxi. These results were similar to the study of Thaewnon-ngiw ${ }^{[36]}$ who found that all scored RAPD-PCR bands generated by different primers across overall species of Pila apple snails in Thailand were polymorphic. So, this suggested the potential of RAPD-PCR analysis for determination of inter- and intraspecific genetic differences of apple snails in Thailand. Similar observations on high genetic polymorphism were detected by RAPD-PCR analysis across investigated species in the mud crabs "Scylla serrata, S. oceanic, and S. tranquebarica",[37] and the cupped oysters of genera Saccostrea "S. cucullata, and S. forskali" and Striostrea "Striostrea (Parastriostrea)" mytiloides ${ }^{[38]}$.

Some authors used morphological characters based-taxonomy and reported that genus Chambardia contained two species in Egypt; $C$. rubens and C. letourneuxi ${ }^{[3,7]}$. However, the similarity coefficient matrix and the UPGMA dendrogram obtained in the present study of all primers could confirm that $C$. rubens is clearly very close to $C$. letourneuxi. Similarly, Yoon ${ }^{[39]}$ succeeded to differentiate between Korean scallop populations and Chinese scallop populations from different localities by using RAPD-PCR. The genetic distance between individuals approved the existence of close relatedness in the Korean scallop population. In addition, the hierarchical dendrogram of Euclidean genetic distances individuals of Korean scallop population were fairly distantly related to that of Chinese scallop populations. Thus, it was suggested that the PCR fragments revealed might be valuable as a DNA marker to discriminate between the two geographical populations ${ }^{[39]}$.

In conclusion, the current study revealed that $C$. rubens and $C$. letourneuxi are very closely related species, as they showed similar bands on using the primers UBC477, UBC483, and UBC486. Using of low number of specimens per each species may be attributed to current study limitations. However, further studies are needed in the future aiming to use larger number of each species to verify inter- and intra-specific genetic variation within populations of mutelid species.

\section{COMPLIANCE WITH ETHICAL STANDARDS}

All procedures contributing to this work comply with the ethical standards of the relevant national guides on the care and use of laboratory animals and have been 
approved/authorized by Institutional Animal Care and Use Committee (IACUC) of Faculty of Science, Cairo University, Egypt.

\section{FUNDING SOURCE DISCLOSURE}

This research received no specific grant from any funding agency in the public, commercial, or not-for-profit sectors.

\section{CONFLICT OF INTEREST}

The authors have no potential conflict of interest regarding the content of this article.

\section{REFERENCES}

[1] Bickford, D.; Lohman, D. J.; Sodhi, N. S. et al. (2007). Cryptic species as a window on diversity and conservation. Trends in Ecology and Evolution, 22(3): 148-155.

[2] Lydeard, C. and Lindberg, D. R., 1948- (2003). Molecular Systematics and Phylogeography of Mollusks. Smithsonian Institution, Washington, DC, USA.

[3] Ibrahim, A. M.; Bishai, H. M. and Khalil, M. T. (1999). Freshwater Molluscs of Egypt. National Biodiversity Unit, Egyptian Environmental Affairs Agency, Cairo, Egypt.

[4] Harper, E. M.; Hide, E. A. and Morton, B. (2000). Relationships between the extant Anomalodesmata: a cladistic test. In: The Evolutionary Biology of the Bivalvia (Harper, E. M.; Taylor, J. D. and Crame, J. A., eds). Geological Society Special Publication, 177, pp. 129-143. The Geological Society, London, UK.

[5] El-Assal F. M.; Varjabedian, K. G.; Tawfik, A. R. et al. (2010). Reproduction and genetic variation in two Corbicula species (Bivalvia: Veneroida) from the River Nile in Egypt. Journal of the Pennsylvania Academy of Science, 84: 31-37.

[6] Bardacki, F. and Skibinski D. O. F. (1994). Application of the RAPD technique in Tilapia fish: species and subspecies identification. Heredity, 73: 117-123.
[7] Graf, D. L. and Cummings, K. S. (2007). Preliminary review of the freshwater mussels (Mollusca: Bivalvia: Unionoida) of northern Africa, with an emphasis on the Nile. J Egypt Ger Soc Zool (D. Invertebrate Zoology), 53: 89-118.

[8] Ibrahim, A. M.; Aly, R. H.; Kenchington, E. et al. (2008). Genetic polymorphism among five populations of Pinctada radiate from the Mediterranean coast in Egypt indicated by RAPD-PCR technique. Egyptian Journal of Zoology, 50: 467-477.

[9] Sleem, S. H. and Ali, T. G. (2008). Application of RAPD-PCR in taxonomy of certain freshwater bivalves of genus Caelatura. Global J Mol Sci, 3: 27-31.

[10] Yousif, F.; Ibrahim, A.; Sleem, S. et al. (2009). Morphological and genetic analysis of Meanoides tuberculata populations in Egypt. Global J Mol Sci, 4(2): 112-117.

[11] El-Assal, F. M.; Sabet, S. F.; Varjabedian, K. G. et al. (2014). Pollution of freshwater Coelatura species (Mollusca: Bivalvia: Unionidae) with heavy metals and its impact on the ecosystem of the River Nile in Egypt. Int $\mathbf{J}$ Waste Resources, 4(4): 1000163 (DOI: 10.4172/2252-5211.1000163).

[12] Williams, J. G.; Kubelik, A. R.; Livak, K. J. et al. (1990). DNA polymorphisms amplified by arbitrary primers are useful as genetic markers. Nucleic Acids Res, 18(22): 6531-6535.

[13] Perez, T.; Alboronz, J. and Dominguiez, A. (1998). An evaluation of RAPD fragment reproducibility and nature. Molecular Ecology, 7(10): 1347-1357.

[14] Abdellatif, K. F. and Khidr, Y. A. (2010). Genetic diversity of new maize hybrids based on SSR markers as compared with other molecular and biochemical markers. J Crop Sci Biotech, 13: 139-145. 
[15] Rohlf, F. J. (2009). NTSYSpc Numerical Taxonomy and Multivariate Analysis, version 2.2, Getting Started Guide. Applied Biostatistics Inc., Port Jefferson, NY, USA.

[16] Real, R. and Vargas, J. M. (1996). The probabilistic basis of Jaccard's index of similarity. Systematic Biology, 45(3): 380-385.

[17] Sneath, P. H. A. and Sokal, R. R. (1973). Numerical Taxonomy: The Principles and Practice of Numerical Classification. Freeman, San Francisco, CA, USA.

[18] Herrera, N. D.; ter-Poorten, J. J.; Bieler, R. et al. (2015). Molecular phylogenetics and historical biogeography amid shifting continents in the cockles and giant clams (Bivalvia: Cardiidae). Molecular Phylogenetics and Evolution, 93: 94106.

[19] Espiñeira, M.; Gonzalez-Lavin, N.; Vieites, J. M. et al. (2009). Development of a method for the genetic identification of commercial bivalve species based on mitochondrial 18S rRNA sequences. J Agric Food Chem, 57(2): 495-502.

[20] Cartaxana, A. (2015). Morphometric and molecular analyses for populations of Palaemonlon girostris and Palaemon garciacidi (Crustacea, Palaemonidae): Evidence for a single species. Estuarine, Coastal and Shelf Science, 154(5): 194-204.

[21] Watters, G. T. (1994). Form and function of unionoidean shell sculpture and shape (Bivalvia). American Malacological Bulletin, 11: 1-20.

[22] Zieritz, A.; Hoffman, J. I.; Amos, W. et al. (2010). Phenotypic plasticity and genetic isolation-by-distance in the freshwater mussel Unio pictorum (Mollusca: Unionoida). Evolutionary Ecology, 24: 923-938.

[23] Zieritz, A.; Gum, B.; Kuehn, R. et al. (2012). Identifying freshwater mussels (Unionoida) and parasitic glochidia larvae from host fish gills: a molecular key to the North and Central European species. Ecology and Evolution, 2(4): 740-750.

[24] Lobato Paraense, W.; Pointier, J. P.; Delay, B. et al. (1992). Biomphalaria prona (Gastropoda: planorpidae): a morphological and biochemical study. Mem Inst Oswaldo Cruz, Rio de Janeiro, 87(2): 171-179.

[25] Spatz, L.; Vidigal, T. H. D. A.; Silva, M. C. A. et al. (2000). Characterization of Biomphalaria orbignyi, Biomphalaria peregrina and Biomphalaria oligoza by polymerase chain reaction and restriction enzyme digestion of the internal transcribed spacer region of the RNA ribosomal gene. Mem Inst Oswaldo Cruz, Rio de Janeiro, 95(6): 807-814.

[26] Larson, S. E.; Anderson, P. L.; Miller, A. N. et al. (1996). Use of RAPDPCR to differentiate genetically defined lines of an intermediate host of Schistosoma mansoni, Biomphalaria glabrata. J Parasitol, 82(2): 237-244.

[27] Abdel-Hamid, A. Z.; de Molfetta, J. B.; Fernandez, V. et al. (1999). Genetic variation between susceptible and nonsusceptible snails to Schistosoma infection using random amplified polymorphic DNA analysis (RAPDs). Rev Inst Med Trop S Paulo, 41(5): 291-295.

[28] Spada, R. G. M.; Da Silva, D.; AbdelHamid, A. Z. et al. (2002). Genetic markers between Biomphalaria glabrata snails susceptible and resistant to Schistosoma mansoni infection. Mem Inst Oswaldo Cruz, Rio de Janeiro 97(1): 53-58.

[29] Da Silva, D.; Spada, R. G.; SobralHamaguchi, S. S. et al. (2004). Biomphalaria tenagophila: genetic variability within intermediate snail hosts susceptible and resistant to Schistosoma mansoni infection. Parasite, 11: 43-49.

[30] Bin Dajem, S. M.; Ibrahim, E. H.; Al-Quraishy S. A. et al. (2011). 
Fingerprint of Biomphalaria arabica, the intermediate host of Schistosoma mansoni in Saudi Arabia, using RAPD-PCR. Gene, 485(2): 69-72.

[31] Oliveira, A. L. D.; Da Silva, D.; Manzano, B. C. et al. (2010). Genetic differences between strains of Biomphalaria glabrata (Planorbidae) that are susceptible and unsusceptible to schistosomiasis. Genet Mol Res, 9(3): 1450-1459.

[32] Abdel-Hamid, A. Z.; Rawi, S. M. and Arafa, A. F. (2006). Identification of a genetic marker associated with the resistance to Schistosoma mansoni infection using random amplified polymorphic DNA analysis. Mem Inst Oswaldo Cruz, Rio de Janeiro, 101(8): 863-868.

[33] Oliveira, A. L. D.; Da Silva, D.; Zanotti-Magalhaes, E. M. et al. (2008). Schistosome/mollusk: genetic compatibility. Genet Mol Res, 7(2): 518-526.

[34] Teixeira, K. N.; Souza, K. N.; Vidigal, T. H. D. A. et al. (2010). Size polymorphism in alleles of the myoglobin gene from Biomphalaria mollusks. Genes, 1(3): 357-370.
[35] Mandahl-Barth, G. (1988). Studies on African Freshwater Bivalves. Danish Bilharziasis Laboratory, Charlottenlund, Denmark.

[36] Thaewnon-ngiw, B.; Klinbunga, S.; Phanwichien, K. et al. (2004). Genetic diversity and molecular markers in introduced and Thai native apple snails (Pomacea and Pila). Journal of Biochemistry and Molecular Biology, 37(4): 493-502.

[37] Klinbunga, S.; Ampayup, P. and Tassanakajon, A. (2000). Development of species-specific markers of the tropical oyster (Crassostrea belcheri) in Thailand. Mar Biotechnol, 2: 476484.

[38] Klinbunga, S.; Ampayup, P. and Tassanakajon, A. (2001). Genetic diversity and molecular markers of cupped oysters (genera Crassostrea, Saccostrea, and Striostrea) in Thailand revealed by randomly amplified polymorphic DNA analysis. Mar Biotechnol, 3: 133-144.

[39] Yoon, J.-M. (2017). Genetic distances of scallop (Chlamys farreri) populations investigated by PCR procedure. Dev Reprod, 21(4): 435440.

\section{How to cite this article:}

Fol, M. F.; Morad, M. Y.; Gamil, I. S.; Sabet, S. F. and Mansour, R. M. (2021). Genetic relationships among four mutelid species (Bivalvia: Unionida) in Egypt revealed by RAPD-PCR technique. Egyptian Journal of Zoology, 75: 1-13 (DOI: 10.12816/ejz.2020.44427.1041). 
العلاقة الجينية لأربعة أنواع من المحاريات النهرية ”BIVALVIA: UNIONIDA“ في مصر "RAPD-PCR" بواسطة تقنية

منى فتحى فل1، مصطقى يحيى مراد²، ايرين سامح جميل² سلوى فروق ثابت1، رضا محمد منصور2

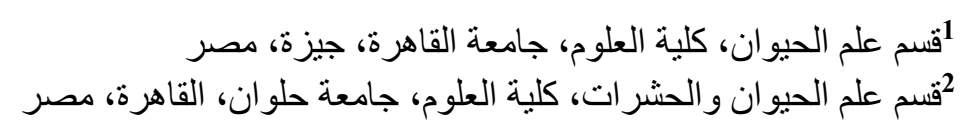

يعتبر تفاعل البلمرة المتسلسل المُعتمد على التضاعف العشو ائى متعدد الأشكال للانا (RAPD-PCR) من الطرق البسيطة

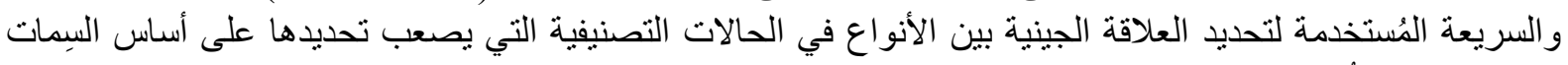

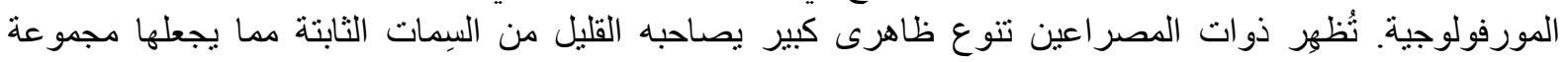

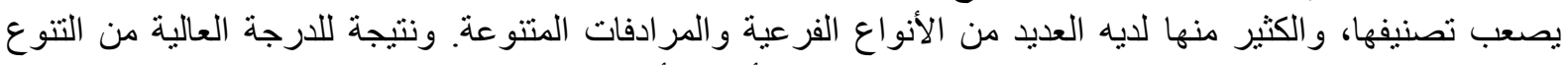

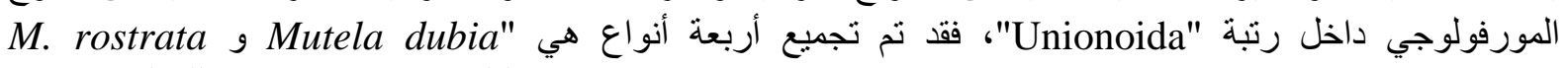

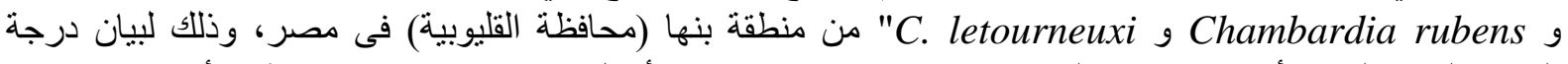

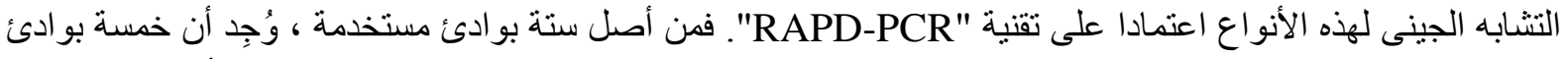

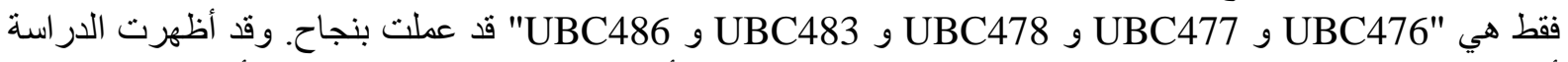

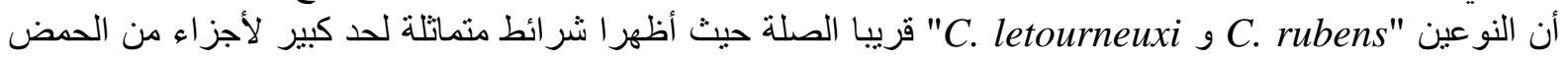

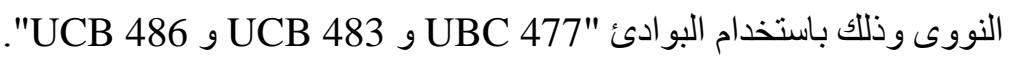

